\title{
Analisis Konsep Pendidikan Islam Humanisme Religius Menurut Abdurrahman Mas'ud
}

\author{
Imam Mukhyidin
}

Universitas Islam Indonesia

Email: imammstars@gmail.com

Junanah

Universitas Islam Indonesia

Email: junanah@uii.ac.id

Mohamad Joko Susilo

Universitas Islam Indonesia

Email: mjs.uii82@gmail.com

\begin{abstract}
Abstrak
Dalam era globalisasi saat ini, pendidikan Islam di Indonesia menghadapi banyak masalah, antara lain: degradasi moral, hilangnya semangat untuk meneliti, serta hilangnya keberanian dan kepercayaan diri. Fokus dalam artikel hasil penelitian ini adalah (a) bagaimana konsep humanisme religius dalam pendidikan Islam? dan (b) bagaimana implikasi konsep humanisme religius menurut perspektif Abdurahman Mas'ud pada pendidikan formal di Indonesia? Penelitian ini merupakan penelitian kualitatif deskriptif dengan studi pustaka. Dengan sumber data primer berasal dari wawancara dan sumber sekunder berasal dari publikasi ilmiah berupa buku, jurnal, artikel, serta hasil penelitian lain Temuan penelitian menunjukkan bahwa pendidikan Islam humanisme religius merupakan proses pembentukan karakter, akhlak dan wawasan serta ilmu pengetahuan dengan cara menempatkan manusia sebagai manusia dengan landasan agama yang disertai hubungan manusia dengan Allah SWT dan sesama manusia atau hablun minallah dan hablun minnas. Implementasinya lebih fokus kepada aspek common sense, individualisme menuju kemandirian, thirst of knowledge, pendidikan pluralisme, kontekstualisme lebih mementingkan fungsi dari simbol, dan keseimbangan antara reward and punishment dalam proses kegiatan belajar mengajar di sekolah/madrasah. Implikasi pendidikan
\end{abstract}


Imam Mukhyidin, Junanah, Mohamad Joko Susilo

Islam humanisme religius terjadi dalam proses pendidikan di madrasah dan Universitas Islam dengan strategi menciptakan kombinasi yang seimbang antara pendekatan dan tujuan, keseimbangan antara orientasi dan informasi, menciptakan iklim/budaya akademik yang mendukung, dan membuat kurikulum yang berkarakteristik.

Kata kunci: pendidikan Islam; humanisme religius; Abdurrahman Mas'ud; madrasah; 


\section{Analysis of The Concept of Religious Humanism Islamic Education According to Abdurrahman}

Imam Mukhyidin

Universitas Islam Indonesia

Email: imammstars@gmail.com

Junanah

Universitas Islam Indonesia

Email: junanah@uii.ac.id

Mohamad Joko Susilo

Universitas Islam Indonesia

Email: mjs.uii82@gmail.com

\section{Abstract}

In the current era globalization, Islamic education in Indonesia face many problems, including: moral degradation, loss of enthusiasm for research, and loss of courage and confidence. Focus of this research is (a) what is the concept of religious humanism in Islamic education? and (b) what are the implications of the concept of religious humanism from Abdurahman Mas'ud's perspective on formal education in Indonesia? This research is a descriptive qualitative research with literature study. The primary data source comes from interviews and secondary sources come from scientific publications in the form of books, journals, articles, and other research results. The research findings show that religious humanism Islamic education is a process of character building, morals and insight as well as science by placing humans as humans with a religious foundation accompanied by human relations with Allah SWT and fellow humans or hablum minallah and hablum minnas. Its implementation is more focused on aspects of common sense, independent individualism, thirst of knowledge, education of pluralism, contextualism is more concerned with the function of symbols, and the balance between reward and punishment in learning process. The implication of Islamic education on religious 
humanism occurs in educational process in madrassas and Islamic universities with a strategy of creating a balanced combination of approaches and goals, balancing orientation and information, creating a supportive academic climate/culture, and creating a characteristic curriculum.

Keywords: Islamic education; religious humanism; Abdurrahman Mas'ud; madrasas;

\section{PENDAHULUAN}

Pendidikan merupakan usaha sadar dan terencana untuk mewujudkan suasana belajar dan proses pembelajaran agar peserta didik secara aktif mengembangkan potensi dirinya untuk memiliki kekuatan spiritual keagamaan, pengendalian diri, kepribadian, kecerdasan, akhlak mulia, serta keterampilan yang diperlukan dirinya, masyarakat, bangsa dan Negara ${ }^{1}$. Adanya pendidikan ini diselenggarkan dengan tujuan untuk mengembangkan potensi peserta didik agar menjadi manusia yang beriman dan bertakwa kepada Tuhan Yang Maha Esa, berakhlak mulia, sehat, berilmu, cakap, kreatif, mandiri, dan menjadi warga negara yang demokratis serta bertanggung jawab ${ }^{2}$. Pendidikan Islam sebagai bentuk manifestasi dari cita-cita hidup Islam untuk melestarikan, mengalihkan, menanamkan (internalisasi) dan mentransformasikan nilai-nilai Islam kepribadian generasi penerusnya, sehingga nilainilai kultural religius tetap berfungsi dan berkembang dalam masyarakat dari waktu ke waktu ${ }^{3}$. Pendidikan Islam sifatnya menyeluruh, bersumber dari nilai-nilai agama Islam, penuh

1 Undang-Undang Republik Indonesia Nomor 20, “Undang-Undang Republik Indonesia Nomor 20" (2003).

2 Undang-Undang Republik Indonesia Nomor 20.

3 Nur Uhbiyati, Ilmu Pendidikan Islam (IPI), 2nd ed. (Bandung: Pustaka Setia, 1997). 
keseimbangan antara materi dan spiritual untuk mencapai kebahagiaan dunia dan akhirat ${ }^{4}$.

Adapun pendidikan Islam yang humanisme religius yakni konsep pendidikan yang memanusiakan manusia, juga mengembangkan kemampuan yang dimiliki, baik intelektual maupun religius tanpa meninggalkan nilai-nilai agama yang mendasarinya ${ }^{5}$, bertujuan untuk membentuk insan kamil ${ }^{6}$, serta pengembangan ilmu pengetahuan yang tidak terlepas dari nilai-nilai keagamaan dan kebudayaan ${ }^{7}$. Humanisme religius adalah konsep keagamaan yang menempatkan manusia serta upaya humanisasi ilmu-ilmu dengan tetap memperhatikan tanggungjawab hablum minallah dan hablum minannas ${ }^{8}$. Humanisme dalam Islam terumuskan dalam konsep khalifatullah dalam Islam.

Tujuan utama pendidikan Islam humanisme religius yaitu; meningkatkan kualitas budaya, menghasilkan pemikiran yang otonom dan kritis, dan membentuk kepribadian yang insan kamil. Adapun strategi dalam pelaksanaan pendidikan Islam religious humanism antara lain: terdapat kombinasi yang seimbang antara pendekatan dan tujuan, terdapat keseimbangan antara orientasi dan informasi, memiliki iklim pendidikan atau budaya akademik yang

4 Ida Nurjanah, "Paradigma Humanisme Religius Pendidikan Islam: Telaah Atas Pemikiran Abdurrahman Mas'ud," MISYKAT: Jurnal Ilmu-Ilmu Al-Quran, Hadist, Syari'ah Dan Tarbiyah 3, no. 1 (2018): 155-70, https://doi.org/10.33511/misykat.v3n1.155; Muhammad Muntahibun Nafis, Ilmu Pendidikan Islam (Yogyakarta: Teras, 2011).

5 Nurjanah, "Paradigma Humanisme Religius Pendidikan Islam: Telaah Atas Pemikiran Abdurrahman Mas'ud"; Zainul Arifin, "Nilai Pendidikan HumanisReligius," An-Nuha 1, no. 2 (2014): 53-80. 1992).

6 Achmadi, Islam Paradigma Ilmu Pendidikan (Yogyakarta: Aditya Media, 7 Abdurrahaman Mas'ud, Menuju Paradigma Islam Humanis (Yogyakarta: Gama Media, 2003).

8 Arifin, "Nilai Pendidikan Humanis-Religius." 
mendukung, kurikulum yang mencolok dan berkarakteristik, dan hubungan dan komunikasi yang baik dalam pendidikan9.

Sesuai dengan amanah undang-undang sistem pendidikan nasional pada Bab I Pasal 1 bahwa untuk mewujudkan tujuan pendidikan kunci utama yang harus diwujudkan adalah menciptakan suasana belajar dan pembelajaran antara pendidik, peserta didik, dan setiap warga sekolah/madrasah. Proses penciptaan tersebut tentunya tidak terlepas dari interaksi yang harmonis dan humanis antar setiap orang yang terlibat dalam proses pendidikan. Sikap mengedepankan tepo sliro, hormat menghormati, saling menjaga, merupakan modal dasar terjalinnya komunikasi yang humanis untuk memudahkan tercapainya tujuan bersama. Apalagi kondisi pendidikan yang ada di jenjang formal di Indonesia tidaklah homogen namun sangat heterogen dan multikultural, baik dari sisi religius, suku, bahasa, dan geografis yang menunjukkan kebhinnekaan ${ }^{10}$.

Indonesia sudah memiliki sebuah paradigma pendidikan yang humanis atas segala kondisi pendidikan yang multikultural. Jika melihat latarbelakang kultur budaya dan sosial masyarakat serta dari paradigma tujuan pendidikan di Indonesia, maka sudah sepantasnya jika pendidikan humanis religius patut dikembangkan dalam lembaga pendidikan di Indonesia. Hal ini penting untuk mengembangkan potensi peserta didik dengan kondisi yang beraneka ragam latar belakangnya.

9 Shokhibul Mighfar, “Menggagas Pendidikan Humanis Religius: Belajar Dari Model Pendidikan Pesantren," JPII (Jurnal Pendidikan Islam Indonesia) 2, no. 2 (2018): 159-80, https://doi.org/10.35316/jpii.v2i2.69.

10 Hijrian A. Prihantoro, "Islam Nusantara Dan Filsafat Orientasi Bangsa; Dialektika Modernitas Beragama Dalam Negara Berbudaya," Millah 16, no. 2 (2017): 203-34, https:/ / doi.org/10.20885/millah.vol16.iss2.art3. 
Fakta perkembangan pendidikan Islam di Indonesia mengalami berbagai permasalahan seperti: degradasi moral11, hilangnya semangat meneliti12, hilangnya sikap keberanian dan percanaan dan pendidikan.

Oleh sebab itu, dalam tulisan ini perlu dilaksanakan untuk menjawab berbagai permasalahan pendidikan yang terjadi di Indonesia. Sebagaimana gagasan humanisme religius sebuah konsep yang cocok untuk diterapkan dalam proses pendidikan saat ini. Tuntutan pendidikan Islam saat ini mengharusan lulus dengan berprestasi yang baik dalam bidang akademik, shalih dalan kehidupan sosial serta taat dalam kehiidupan religius dan konsep humanisme religius yang digagas oleh Abdurrahman Mas'ud berusaha mewujudkan tuntutan pendidikan Islam tersebut. penelitian ini berusaha mengkaji pemikiran dari Abdurrahman Mas'ud yang saat ini masih aktif mengajar di beberapa kampus di Indonesia sehingga tidak sulit untuk menggali pemikiran beliau lewat wawancara langsung. Ada 2 hal yang menarik dari pemikiran beliau yang berbeda dengan pemikiran-pemikiran tokoh lainya.

$\begin{array}{ccccc} & 11 \text { Wisnu Yusep, "Tawuran Pelajar Di Bekasi, Satu Pelajar Tewas Ditabrak } \\ \text { Motor } & \text { Lalu } & \text { Dibacok } & \text { Berkali-Kali," } & \text { Okezone, } \\ \text { 2020, }\end{array}$ https:/ / megapolitan.okezone.com/read/2020/07/23/338/2251089/tawuran-pelajardi-bekasi-satu-pelajar-tewas-ditabrak-motor-lalu-dibacok-berkali-kali; Aam Aminullah, "Sederet Kasus Tawuran Antar-Pelajar Di Tengah Pandemi Corona," Kompas.com, 2020, https://regional.kompas.com/read/2020/03/28/12252161/sederet-kasustawuran-antar-pelajar-di-tengah-pandemi-corona?page=all; Antaranews.com, "Dua Remaja Tewas Akibat Tawuran Di Matraman," Antaranews.com, 2020, https:/ / www.antaranews.com/ berita/1675558/dua-remaja-tewas-akibat-tawuran-dimatraman; Akfa Syaufika Rahman, Siti Nurjannah, and Intan Rahma Utami, "Dampak Maraknya Kekerasan Antarpelajar Terhadap Motivasi Belajar," Jurnal Program Kreativitas Mahasiswa 2, no. 2 (2018): 63-69.

12 Sahri Ramadan, "Pengaruh Game Online Terhadap Prestasi Belajar Siswa," Kompasiana.com, 2020, https://www.kompasiana.com/sahriramadan/56e805ebd59273b212e2bd9e/pengaruh -game-online-terhadap-prestasi-belajar-siswa?page=all; Gustina, "Motivasi Belajar Anak-Anak Nelayan Di Madrasah Aliyah," Ta'dib 16, no. 2 (2016): 160-67, https://doi.org/10.31958/jt.v16i2.248. 
Pertama dari segi riwayat pendidikanya yang berasal dari pesantren dan pernah belajar di Amerika Serikat sehingga memberikan nuansa keilmuan yang lebih humanis sekaligus memberi warna pada religusitasnya. Hal menarik lainya yaitu tentang gagasan humanisme religiusnya yang mampu menjawab tantangan pendidikan pada beberapa era kedepan. Hal ini dibuktikan dengan pemikiran humanisme religiusnya yang dicetuskan sekitar tahun 2003 namun memiliki kemiripan dengan mindset berfikir pada kurikulum 2013 yang dipakai saat ini. Atas berbagai pertimbangan diatas maka penelitian ini berusaha untuk mengkaji mengenai Analisis Konsep Pendidikan Islam Humanisme Religius Menurut Abdurahman Mas'ud

\section{METHODOLOGI}

Artikel ini dikembangkan dari penelitian kepustakaan, artinya penelitian yang bersifat kepustakaaan murni yang data-datanya didasarkan atau diambil dari wawancara dan bahan-bahan tertulis baik yang berupa buku-buku pereodikal, naskah-naskah, catatancatatan kisah sejarah tertulis, dokumen dan materi pustaka lainya yang terdapat dalam perpustakaan. Penelitian ini termasuk penelitian kualitatif deskriptif dan termasuk jenis penelitian bibliografi karena berusaha mengumpukan data, menganaisis dan membuat interpretasi tentang pemikiran tokoh Abdurrahman Mas'ud. Pendekatan yang digunakan dalam penelitian ini adalah pendekatan historis-filosofis.

Teknik pengumpulan data dalam penelitian ini menggunakan metode: 1) wawancara dimana dalam penelitian ini menggunakan wawancara tidak terstruktur atau bentuk wawancara yang tidak menggunakan pedoman yang lengkap dan sistematis terhadap Abdurrahman Mas'ud untuk memperoleh berbagai informasi yang berkaitan dengan penelitian khususnya dalam hal pendidikan Islam 
humanisme religius; dengan beberapa butir soal yaitu sebagai berkut: a) Apa yang menjadi permasalahan utama bagi pendidikan Islam sehingga pendidikan Islam humanisme religius perlu untuk dikembangkan di Indonesia?, b) Aspek apa saja yang perlu diterapkan dalam mengembangkan pendidikan Islam humanisme religius di Indonesia, dalam rangka memperbaiki sistem pendidikan Islam?, c) Kurikulum 2013 khususnya untuk mata pelajaran PAI yang saat ini diterapkan oleh pemerintah, apakah sudah sesuai dengan tujuan pendidikan Islam yang dicita-citakan? 2) dokumentasi, untuk mendapatkan data yang berasal dari bukubuku, jurnal, makalah dan berbagai karya Abdurahman Mas'ud yang relevan dengan penelitian ini. Dari berbagai sumber dokumentasi tersebut dilakukan agar mendapatkan sumber data yang lebih lengkap menyeluruh.

Sumber data primer yang akan dipakai dalam penelitian ini yaitu wawancara langsung kepada penulis Abdurrahman Mas'ud secara umum berisi pertanyaan tentang latarbelakang pemikiran beliau, konsep dasar humanisme religius dan implikasi humanisme religius terhadap pendidikan di Indonesia; dan buku beliau yang berjudul "Mengagas format pendidikan non dikotomik" (Humanisme Pendidikan Religius Sebagai Paradigma Pendidikan Islam) karena melalui buku tersebut paling banyak mewakili pemikiran tokoh tentang humanisme religius, sedangkan sumber data sekunder yaitu data yang terdiri dalam bentuk buku, koran, dokumen, dan lain-lain yang sifatnya mendukung data primer.

Dalam penelitian ini teknik analisis data yang digunakan adalah metode deskriptif dengan teknik analisis isi. Metode deskriptif yaitu suatu metode dalam penelitian status sekelompok manusia suatu objek, suatu kondisi, suatu sistem pemikiran atau kelas peristiwa pada masa sekarang yang bertujuan untuk membuat 
lukisan, gambaran dan deskripsi secara sistematis ${ }^{13}$. Metode deskriptif digunakan untuk menganalisis dan mendeskripsikan konsep pendidikan humanisme religius Abdurrahman Mas'ud. Sedangkan teknik analisis isi adalah suatu teknik penelitian ilmiah yang ditujukan untuk mengetahui gambaran karakteristik isi dan menarik inferensi dari isi ${ }^{14}$. Ada 3 fase pokok dalam penelitian ini yaitu: pertama, metode berfikir intepretatif (intrepretasi data) metode ini digunakan untuk mengintrepretasikan beberapa maksud tentang konsep pendidikan humanisme religius menurut Abdurahman Mas'ud. Kedua, metode berfikir reflektif (reflektif thinking) yaitu sebuah cara untuk mengkombinasikan cara berfikir induktif dan deduktif. Ketiga, yaitu berfikir kontekstual dengan menyesuaikan hasil pemikiran konsep pendidikan humanisme religius menurut Abdurahman Mas'ud dengan situasi pada masa kini.

\section{HASIL DAN PEMBAHASAN}

\section{Konsep Dasar Pendidikan Islam Humanisme Religius}

Konsep dasar pendidikan Islam humanism religius berawal dari segi sejarah kemunduran pendidikan Islam yang ditengarai munculnya cara berfikir serba dikotomis dan hitam putih sebagian besar umat Islam, seperti Islam versus non Islam, timur-Barat, dan ilmu-ilmu agama versus ilmu sekuler ${ }^{15}$. Atas dasar pola berfikir yang dikotomis tersebut ternyata telah menempatkan Islam didalam era kemunduranya sejak terjadinya era renaissance Barat. Adanya sebuah cara berfikir yang lebih mementingkan aspek keakhiratan dan meninggalkan aspek keduniaan telah menghentikan proses berfikir

13 Ajat Rukajat, Pendekatan Penelitian Kuantitatif(Sleman:CV Budi Utama,2018). hlm.1.

14 Eriyanto, Analisis Isi: Pengantar Metodologi Untuk Penelitian Ilmu Komunikai dan Ilmu-Ilmu Sosiallainya, (Jakarta: Prenadamedia Grup,2015).hlm. 15.

15 Abdurrahman Mas'ud, Menggagas Format Pendidikan Non Dikotomik (Yogyakarta: Gama Media, 2002).hlm. 131. 
kritis dan memulai pola berfikir yang serba taklid pada ulama terdahulu. Untuk itu diperlukan sebuah upaya untuk mengembaikan kejayaan islam, salah satunya dengan cara pengembangan konsep pendidikan islam humanisme religius.

Jika mengacu pada pemikiran Abdurrahman Mas'ud tentang pendidikan Islam yang dikemas sesuai dengan pengalaman hidupnya. Ada beberapa karyanya yang memaparkan pendikan pesantren sebagai solusi permasalahan pendidikan Islam di Indonesia. Namun di lain situasi beliau menawarkan solusi pendidikan ala pendidikan Barat. Hal ini tidak lepas dari pengalaman hidup, dan latar belakang pendidikan beliau yang memiliki dua wajah berbeda. Kajian ini akan dijelaskan mengenai Humanisme religius sebagai solusi masalah pendidikan Islam sebagai paduan pemikiran beliau yang pernah mengenyam pendidikan di pesantren dengan nuansa tradisionalnya yang dipadukan dengan pemikiran beliau selama di Amerika dengan nuansa kemodernanya.

Ada alasan mengapa humanisme religius perlu dikembangkan pada pendidikan Islam di Indonesia. Hal ini terjadi karena adanya dualisme pendidikan yang ada di Indonesia. Banyak sekolah yang mengembangkan pendidikan hanya fokus pada pembentukan intelektual. Dan di sisi lain sebagian sekolah mengembangkan pendidikan hanya dari segi agama tanpa wawasan ilmu pengetahuan umum. Berikut adalah pola yang perlu dikembangkan dalam rangka menyelesaikan perbedaan pandangan yang menjadi persoalan dalam pendidikan Islam di Indonesia:

a. Common Sense atau Akal Sehat

Permasalahan yang selama ini dihadapi dalam pendidikan Islam di Indonesia salah satunya adalah proses menghafal materi 
yang terlalu banyak ${ }^{16}$, sehingga mengesampingkan kemampuan berfikir siswa. Hal ini terjadi karena budaya bicara dan menghafal oleh guru dan siswa lebih dominan daripada membaca. Untuk mencapai pendidikan yang humanis maka harus diubah paradigma tersebut. Siswa harus memiliki semangat membaca literasi dan guru harus mampu menumbuhkan kreatifitas siswa termasuk memotivasi budaya penggunaan akal sehat, bukan kemampuan menghafal ${ }^{17}$. Penerapan proses pendidikan di lembaga formal sekolah/madrasah yang masih didominansi dengan kemampuan level rendah (kognitif level 1 /remember) harus diubah menjadi proses pendidikan yang harus mengembangkan model pendidikan why yang menyajikan materi pelajaran yang rasional $^{18}$, dengan kata lain proses pendidikan harus diarahkan untuk mendewasakan dan merubah cara beripikir menghafal, mengingat ke dalam proses berpikir kognitif level tinggi seperti menganalisa, membandingkan. Dengan demikian, dalam memahami materi pendidikan Islam tidak hanya berpusat pada penghafalan materi tetapi perlu dikaitkan kedalam berbagai perspektif, meskipun pada akhirnya bermuara juga dalam ranah agama Islam.

b. Individu Menuju Kemandirian

Salah satu orientasi pendidikan adalah terwujudnya kemandirian siswa ${ }^{19}$. Kemandirian siswa bermakna kemampuan

16 Hasanudin Abdurakhman, "Menghafal Itu Bukan Belajar," Kompas.com, accessed 20, August 2020, https:/ / edukasi.kompas.com/read/2016/12/14/15245261/menghafal.itu.bukan.belaja r?page $=$ all.

17 Khoirul Huda, "Problematika Madrasah Dalam Meningkatkan Mutu Pendidikan Islam," Jurnal Dinamika Penelitian 16, no. 2 (December 2, 2016): 309-36, http:/ / ejournal.iain-tulungagung.ac.id/index.php/dinamika/article/view/215.

18 Abdurrahman Mas'ud, Mendakwahkan Smiling Islam: Dialog Kemanusiaan Islam Dan Barat (Tangerang: Pustaka Compass, 2019).hlm. 304.

19 Toni Nasution, "Membangun Kemandirian Siswa Melalui Pendidikan Karakter," IJTIMAIYAH 2, no. 1 (2018): 1-18; Vilma Zydziunaite, Margarita Tereseviciene, and Genutè Gedvilienè, "The Structure of Independent Learning in 
siswa dalam bertanggungjawab atas apa yang menjadi amanah dalam diri siswa tersebut selama dia menjalani proses belajar di sekolah. Dengan harapan siswa memiliki kemampuan kemandirian setelah menjalani pendidikan di lembaga formal sekolah dan siap untuk terjun di masyarakat yang sesungguhnya.

Dalam pendidikan Islam seseorang harus mampu bertanggung jawab atas segala perbuatanya. Untuk itu, perlu menginterpretasi kembali ajaran-ajaran Islam yang selama ini difahami secara pasif agar menjadi aktif ${ }^{20}$. Dalam hal ini pendidikan Islam sebaiknya tidak terlalu fokus pada ketakutan seseorang jika tidak melaksanakan perbuatan tertentu akan mendapat hukuman di akhirat. Lebih dari itu, siswa harus mampu memahami bahwa perbuatan baik dan buruk yang ia lakukan adalah bentuk peertanggungjawanbannya di dunia atas dampak sosial yang terjadi. Pada akhirnya, secara sadar seseorang akan paham atas perbuatan yang ia lakukan, bukan karena ancaman dan imbalan keakhiratan.

Proses pendidikan harus mampu menjadikan siswa memiliki kemampuan berpikir yang mengarah pada kedewasaan dan kematangan diri. Sehingga bisa membedakan baik buruk, halal haram, benar salah. Kemampuan tersebut sebagai wujud riil kematangan berpikir yang dapat digunakan sebagai bekal dalam proses menuju kemandirian diri dan tanggungjawab. Hasil pendidikan tidak hanya ditunjukkan dengan angka-angka akademik, namun ada yang lebih esesnsi yakni terjadinya perubahan diri menjadi lebih dewasa berpikir dan bertindak, memiliki kemampuan mengontrol dan mengendalikan diri, matang dalam mengambil keputusan, dan memiliki prinsip yang kuat atas

Higher Education: Students' Attitude," in Proceeding of the International Scientifical Conference, vol. 1, 2014, 336-334, https:// doi.org/10.17770/sie2014vol1.774.

20 Mas'ud, Mendakwahkan Smiling Islam: Dialog Kemanusiaan Islam Dan Barat.hlm. 59. 
keyakinan/kebenaran yang diperolehnya dari proses ilmiah maupun pemikiran yang mendalam.

c. Thirst for Knowledge

Pendidikan Islam harus mampu membiasakan siswanya untuk memiliki semangat meneliti segala hal yang dapat mengembangkan potensi dirinya ${ }^{21}$. Semangat untuk meneliti sebenarnya sudah dijelaskan di dalam Al Quran berupa seruan kepada manusia untuk melaksanakan iqra' atau membaca sebagai modal awal semangat meneliti sesuai dengan ayat pertama surah Al Alaq. Ayat tersebut memiliki arti penting bahwa membaca adalah aktifitas intelektual yang terbukti mampu mengubah peradaban manusia dari masa kegelapan dan membawa pada peradaban yang tinggi ${ }^{22}$. Hal ini sudah dicontohkan oleh para ulama pada masa abad pertengahan dimana para tokoh seperti Ibn Sinna, Ibn Rush, Al Faraby, adalah sosok-sosok yang memiliki keahlian agama dan dipadu dengan wawasan umum, menghasilkan era keemasan dalam peradaban Islam. Namun sekarang budaya tersebut telah berpindah pada peradaban Barat. Umat Islam sendiri justru mengembangkan budaya menghafal, sehingga yang terjadi saat ini Barat mendominasi peradaban dunia.

Esensi tentang semangat meneliti ini lebih ditonjolkan pada kepekaan diri untuk bisa menangkap pokok-pokok persoalan dalam kehidupan sehingga bisa menemukan akar-akar masalah. Temuan tersebut kemudian didekati dengan pendekatan ilmiah dengan

21 Ana Logar, Cirila Peklaj, and Vesna Ferk Savec, "Effectiveness of Student Learning during Experimental Work in Primary School," Acta Chimica Slovenica 64, no. 3 (2017): 661-71, https://doi.org/10.17344/acsi.2017.3544; Raymond Li and Tina Wong, "Teaching Them before We Teach: The Effectiveness of Conducting Classroom Experiments before Teaching the Underlying Theory," IAFOR Journal of Education 6, no. 3 (2018): 79-92, https:/ / doi.org/10.22492/ije.6.3.05.

22 Abdurrahman Mas'ud, Antologi Studi Agama Dan Pendidikan (Semarang: Aneka Ilmu, 2013).hlm. 69. 
penguasaan pengetahuan mengenai metodologi ilmiah, sehingga persoalan tersebut dapat diselesaikan dan dibuktikan dengan pendekatan-pendekatan yang logis dan bisa dipertanggungjawabkan secara ilmiah.

d. Kontekstualisme lebih Mementingkan Fungsi daripada Simbol

Maksudnya adalah kegunaan/fungsi akan ilmu pengetahuan seharusnya lebih penting daripada simbol status sosial. Pertimbangan untuk menentukan fungi dan rasional harus lebih diutamakan daripada sekedar simbol dan status ${ }^{23}$. Permasalahan seperti ini banyak terjadi dikalangan umat Islam, dimana umat Islam selalu mengagungkan para ulama mereka yang pernah berjaya pada masa lampau. Namun, untuk saat ini umat Islam tidak mampu mencontoh apa yang mereka lakukan pada masa itu. Islam pada era sekarang lebih banyak mengutip ilmu dari ulama masa lampau. Tetapi penerapan dan fungsi bagaimana tidak banyak dilaksanakan.

Budaya takliq buta dalam hal-hal tertentu bisa dibenarkan, namun dalam urusan-urusan keduniawiaan perlu menjadi pertimbangan-pertimbangan dari cara-cara berpikir yang komprehensif dan melihat sisi madhorot dan maslahat atas hal-hal yang dihadapinya. Maka mengangungkan simbolisasi, pengkultusan dalam hal-hal keduniawiaan justru akan menjebak matinya kekritisan berpikir seseorang. Berbeda pendapat itu sebuah rahmat dan disitulah indahnya ilmu pengetahuan.

e. Keseimbangan Antara Reward and Punishment

Reward and Punishment sering kali dipraktekkan dalam dunia pendidikan yang bertujuan sebagai strategi perubahan perilaku siswa ${ }^{24}$. Idealnya, dalam mempraktekkan punishment dan reward

23 Mas'ud, Menggagas Format Pendidikan Non Dikotomik.hlm. 170.

24 Claudiu Langa, "Rewards and Punishments Role in Teacher-Student Relationship from the Mentor's Perspective," Acta Didactica Napocensia 7, no. 4 (2014): 7-12. 
paling efektif yaitu punishment harus dikurangi dan reward perlu ditekankan pelaksanaannya ${ }^{25}$. Permasalahan yang terjadi di Indonesia yaitu guru lebih banyak memberi hukuman daripada hadiah atau pujian dalam setiap aktifitas pembelajaran di sekolah. Hal ini memberi dampak pada sikap mental peserta didik yang buruk. Sikap mental peserta didik menjadikan ketakwaan mereka berlandaskan ketakutan, bukan atas dasar kesadaran. Akibatnya, kreatfitas peserta didik tidak dapat berkembang karena selalu dibayangi dengan keharusan melakukan sesuatu yang belum tentu menjadi bakatnya. Idealnya guru yang membalas perilaku baik dari siswa akan menimbulkan sikap percaya dari siswa. Sebaliknya jika dalam proses pengajaran hanya mengandalkan hukuman, maka dampak yang terjadi pada siswa yaitu hanya menimbulkan kemalasan, ketakutan, dan penurunan semangat ${ }^{26}$. Untuk itu penggunaan reward dan punishment harus dilakukan dengan bijak, sebisa mungkin reward harus lebih dominan daripda punishment. Penerapan punishment jika diperlukan harus dilakukan dalam kondisi, situasi, waktu dan konteks yang tepat.

Dari konsep dasar humanisme religius diatas jika dikembangan lebih jauh meunculkan semangat untuk mengintegrasikan ilmu pengetahuan yang hari ini dikuasai oleh Barat, dengan agama yang saat ini dipegang teguh oleh umat Islam perlu untuk dikembangkan. Karena cukup populer dalam pandangan Islam masa lampau atau masa kejayaan sains bahwa peradaban Islam ilmu dan agama telah terintegrasi, menjadikan Islam sebagai peradaban maju. ${ }^{27}$ Sedangkan sekarang Barat yang menempati tempat itu. Bukan tidak mungkin beberapa waktu yang akan datang giliran umat Islam kembali

25 Mas'ud, Menggagas Format Pendidikan Non Dikotomik.hlm. 172.

26 Ahmad Ali Budaiwi, Imbalan Dan Hukuman Pengaruhnya Bagi Pendidikan Anak (Jakarta: Gema Insani Press, 2002).hlm. 17.

27Zainal Abidin Bagir,Integrasi Ilmu dan Agama: Interpretasi dan Aksi,(Yogyakarta: Mizan, 2005),hlm. 20. 
menjadi peradaban maju. Lebih lanjut kemajuan sebuah peradaban didukung dengan akulturasi dari budaya lain seperti halnya Islam pada masa lampau banyak mempelajari budaya Yunani khususnya dalam filsafat. Transfer of knowledge dari Yunani ke dunia Islam banyak dimotori oleh para penerjemah profesional, demikian pula sejarah terulang (history repeats itself) tatkala Barat belajar dari dunia Islam. Sehinggga untuk mengembangkan Islam yang humanis dan berpangkal pada kemajuan sains, maka sudah saatnya Islam perlu belajar kepada Barat. Meskipun fenomena ini bukanlah hal yang baru. Misalnya tokoh sekaliber Muhamad Abduh juga menikmati pengasingan kehidupan di Paris dan beberapa tahun serta sempat menikmati kota London berkesan di Eropa bahwa, "aku melihat Islam di Eropa, meskipun aku tidak melihat muslim disana. Sebaliknya aku tidak melihat Islam di Mesir, tetapi bertemu banyak muslim disini. ${ }^{28}$ Pada dasarnya tidak ada yang salah tentang budaya Barat yang diadopsi Islam dalam rangka mengembangkan intelektual mereka. Akan tetapi sikap bijaksana dalam memilih dan memilah budaya Barat harus selektif. Karena ada berbagai budaya mereka yang bertolak belakang dengan budaya luhur peradaban timur. Namun secara keseluruhan banyak tokoh dari Indonesia yang sukses dalam menimba ilmu di Barat. Tidak dapat dipungkiri mereka adalah tokoh-tokoh berpengaruh yang pernah belajar dari Barat pada dalam perkembagan peradaban Indonesia seperti Ir Soekarno, Moh Hatta, R.A. Kartini dari golongan nasionalis. Ada juga tokoh dari golongan agama seperti Nur Cholis Majid, Syafii Ma'arif, Amin Rais dan lain sebagainya. ${ }^{29} \mathrm{Hal}$ ini juga sejalan dengan pengalaman Abdurrahman Mas'ud yang pernah belajar baik di pesantren maupun di dunia Barat, bedasarkan wawancara beliau bahwa ada kesinambungan antara belajar di pesantren dan belajar di

28Abdurrahaman Mas'ud, Mendakwahkan Smilling Islam..., hlm. 252.

29Abdurrahaman Mas'ud, Mendakwahkan Smilling Islam..., hlm. 251. 
Barat. Karena 2 lingkungan berbeda tersebut adalah tugas kita selain belajar darinya kita harus mampu mengisi dan memberikan pengaruh terhadap lingkungan itu, bukan terombang-ambing dalam lingkungan baru. ${ }^{30}$

Dialog antara Barat dan Islam merupakan sesuatu yang perlu dilaksanakan. Karena sejarah telah mengajarkan bahwa saat dua dunia yang berbeda itu saling memahami dan saling menghormati serta saling belajar maka yang terjadi adalah kemajuan budaya dan peradaban dari pihak yang hendak belajar. ${ }^{31}$ Hal ini penting karena peradaban Barat memerlukan sesuatu yang tidak dimliki yaitu spiritualisme dan ketuhanan sementara peradaban Islam membutuhkan sesuatu yang tidak dimiliki yaitu ilmu pengetahuan, sains dan teknologi dari negara Barat. Kutipan dari George Sarton "kita sangat bangga dengan peradaban Amerika, tetapi rekornya hanya 3 abad, sangat singkat dibandingkan keseluruhan peradaban manusia. Untuk itu kita senantiasa harus rendah hati. Kebenaran ilmiah berasal dari sumber yang sama, baik dari Barat maupun timur, begitu pula dengan keindahan dan kedermawanan. Siapa bilang antara Barat dan timur tidak pernah bertemu? Dari timur muncul cahaya, dari Barat muncul hukum."32

\section{Relevansi Humanisme Religius dalam Konteks Pendidikan Islam Masa Kini}

a. Implikasi Pendidikan Islam Humanisme Religius di Madrasah

Madrasah merupakan pengembangan pendidikan tertua di Indonesia, yang merupakan pengembangan dari pendidikan pesantren. Lembaga pendidikan ini mengembangkan corak Januari 2020

30 Wawancara dengan Abdurrahman Mas'ud di Yogyakarta, tanggal 25

31Abdurrahaman Mas'ud, Mendakwahkan Smilling Islam..., hlm. 261.

32 Haidar Bagir, Islam Tuhan Islam Manusia: Agama dan Spiritualitas Di Zaman Kacau, (Jakarta:Mizan, 2017), hlm.198. 
pendidikan khas yaitu Islam dengan ditopang dengan pendidikan umum. Sampai saat ini madrasah memiliki kontribusi yang besar bagi pendidikan di Indonesia, hal ini terlihat pada jumlah sekolah madrasah baik di kota dan di desa masih eksis. Namun yang menjadi permasalahan, dari hari ke hari jumlah madrasah di Indonesia semakin bertambah tetapi belum menjadi pilihan utama dalam masyarakat. Beberapa permasalahan pendidikan Islam di madrasah yaitu pertama, kualitas pelayanan yang diberikan oleh madrasah dinilai masih rendah dibandingkan layanan pendidikan dari sekolah umum dan negeri. Kedua, perubahan orientasi masyarakat dimana era industrialisasi telah menyebabkan perubahan orientasi pendidikan masyarakat berubah dari pendidikan untuk mencari ilmu menjadi pendidikan untuk mempersiapkan dunia pekerjaan. Ketiga, pembelajaran madrasah saat ini masih lebih memfokuskan pada masalah-masalah keagamaan, sehingga unsur pengembangan IPTEK cenderung kurang mendapat porsi yang seimbang 33 . Solusi yang harus dilakukan madrasah demi mengembangkan lulusan yang mampu menjawab tantangan zaman diantaranya mengikutsertakan wajahwajah baru dalam tubuh madrasah yang memiliki semangat, inovasi, dan integritas yang tinggi dalam upaya mengembangkan pendidikan ini. Kedua yaitu dengan mengusahakan agar peserta didik berprestasi dan mampu bersaing dengan siswa-siswa di sekolah umum dalam bidang materi umum ${ }^{34}$. Untuk itu materi pelajaran antara agama dan ilmu pengetahuan harus dilaksanakan secara seimbang. Kemudian proses pembelajaran juga harus dilaksanakan dengan cara yang humanis. Artinya siswa diberikan mental percaya kepada diri sendiri yang kuat, sehingga mampu

33 Muhammad Maskur, "Eksistensi Dan Esensi Pendidikan Madrasah Di Indonesia," Jurnal Pendidikan Dan Pembelajaran Dasar 4, no. 1 (2017), https:// doi.org/10.24042/terampil.v4i1.1807.

34 Abdurrahman Mas'ud, Antologi Studi Agama Dan Pendidikan.hlm. 99. 
mengembangkan kreatifitas dan potensi masing-masing. Terakhir yaitu harus ada perhatian yang seimbang dari pemerintah terhadap sekolah negeri dan swasta ${ }^{35}$. Walau bagaimanapun pendidikan adalah hak segala bangsa, sudah sepantasnya pemerintah memberikan kebijakan-kebijakan terhadap sekolah dengan cara yang bijaksana dan secara adil.

Para ahli teori psikologi humanistik adalah pengajur yang kuat pada penemuan dan penyelidikan, dimana siswa mencari jawaban terhadap pertanyaan yang riil, membuat penemuan autonomous (bebas), dan menjadi pencetus dalam belajar yang berdasar pada inisiatifnya sendiri. Dengan kata lain, tidak hanya dimensi afektif yang ingin dikembangkan oleh teori ini tapi juga skill kognitif dan psikomotirik siswa yang akan dikembangkan untuk mencapai keberhasilan akademik.

Ada kesempurnaan yang nampak dari teori pendekatan humanistic ini jika dikaitkan dengan realitas pendidikan di Indonesia. Bahkan tuntutan dalam UU No 14 tahun 2005 tentang guru dan dosen untuk dapat memiliki empat kompetensi dalam pengajaran, yaitu kompetensi pedagogik, kompetensi professional, kompetensi kepribadian, dan kompetensi social. Harapannya tentunya dengan ke empat kompetensi tersebut jika diimplementasikan dalam kegiatan belajar mengajar (KBM) di kelas dengan berbagai pemahaman pendekatan strategi belajar khususnya pada pendekatan humanistic maka diharapkan proses belajar mengajar (PBM) akan berjalan dengan menyenangkan (joyfull learning) sehingga tingkat pemahaman dan penguasaan siswa terhadap mata pelajaran yang diajarkan akan bisa tercapai bahkan terimplementasi dalam ketrampilan dan sikap-sikap siswa sebagai bagian dari insan akademik. 
Untuk itu, berdasarkan dari hasil penyelidikan oleh Carl Rogers $^{36}$ khususnya tentang keberhasilan dalam penerapan teori humanistic untuk pengajaran mata pelajaran di kelas, maka teori humanistic ini dapat direkomendasikan untuk diterapkan dijenjang sekolah formal baik ditingkat dasar, menengah pertama, menengah atas, dan bahkan di perguruan tinggi. Dengan catatan guru ataupun dosen harus benar-benar berangkat dari minat siswa (peminatan) untuk belajar mata pelajaran yang akan diajarkan dan disesuaikan dengan kurikulum yang berlaku. Meski sedikit merepotkan guru atau dosen, namun jika diterapkan dengan baik akan nampak hasil yang mengembirakan bahkan keberhasilan dalam PBM akan dapat terukur dengan otentik.

b. Implikasi Pendidikan Islam Humanisme Religius di Perguruan Tinggi

Permasalahan pada perguruan tinggi Islam secara umum yaitu munculnya image kesenjangan kualitas antara PTN dan PTAI yang pada akhirnya memunculkan pandangan dikotomis bahwa PTN merupakan perguruan tinggi yang memiliki mutu yang lebih baik daripada PTAI. Permasalahan khusus dalam pendidikan tarbiyah di perguruan tinggi Islam yaitu dunia pendidikan Islam diliputi oleh masalah tipikal berupa certificated oriented atau orientasi belajar di kampus hanya sekedar mencari ijazah serta ilmu-ilmu yang diajarkan terlalu umum, sehingga tidak mengacu pada pemecahan masalah ${ }^{37}$. Dampaknya yaitu output yang dihasilkan fakultas tarbiyah adalah pendidik yang kurang kompeten dalam bidangnya dan pada akhirnya lulusan sarjana-sarjana bekerja dengan tidak pada bidangnya. 2012).hlm. 30 .

36 Carl Rogers, On Becoming a Person (Terj.) (Yogyakarta: Pustaka Pelajar,

37 Abdurrahman Mas'ud, Antologi Studi Agama dan Pendidikan...,hlm. 109 
Menurut Abdurrahman, setidaknya ada beberapa langkah yang harus ditempuh untuk memecahkan persoalan-persoalan ini, yaitu sebagai berikut:

a. Karena kemandegan ilmu di IAIN, maka harus ada upaya menjadikan penelitian sebagai budaya dan kebanggaan utama perguruan tinggi Islam yang mengarah pada research university. Meneliti sebagai kebutuhan dasar akademis bagi setiap dosen dan juga mahasiswa. Namun perlu dicatat bahwa hal tersebut tidak akan terwujud tanpa adanya good will dan political will dari elit IAIN dan juga Kementrian Agama.

b. Budaya Islam masa kini, budaya lisan lebih dominan daripada budaya menulis, tradisi bicara lebih dominan daripada tradisi baca, terbukti dari segi literasi Indonesia menempati peringkat bawah sebagai negara yang memiliki minat baca yang kurang. Sehingga merupakan tugas guru dan dosen untuk merubah situasi tersebut. ${ }^{38}$

c. Menciptakan iklim yang sehat bagi tumbuhnya dialog, renewal, dan gagasan-gagasan segar di lingkungan IAIN.

d. Memperkaya modern scholarship dengan informasi dan pengetahuan tentang Islam Indonesia, dinamika kebudayaan lokal, dan tidak ketinggalan tradisi keilmuan Barat.

e. Menghilangkan kesenjangan antara sesama dunia Islam juga antara muslim dan Western scholarship dengan titik tekan pada belajar bersama, networking, research, dan publikasi hasil studi dan penelitian orisinal.

f. Melakukan profesionalisasi pusat-pusat kajian di lingkungan perguruan tinggi agama dalam rangka merespon globalisasi, otonomi daerah, dan future without shock.

38 Wawancara dengan Abdurrahman Mas'ud di Yogyakarta, tanggal 25 Januari 2020. 
g. Mengintensifkan pengiriman dosen untuk studi lebih tinggi dengan pemilihan utama di universitas-universitas yang akrab dengan riset baik di dalam maupun luar negeri. ${ }^{39}$

h. Memasukan 2 bahasa asing yaitu arab dan inggris ke dalam mata kuliah agar lulusan dapat mengikuti perkembangan zaman dan dinamika keilmuan

i. Mengembangkan kemampuan metodologis yang berhibungan dengan filsafat, sejarah, ilmu-ilmu sosial, dan memberikan pendidikan doktriner dan wawasan perlu diseimbangkan. Agar mahasiswa memiliki pandangan yang multidisipliner tentang Islam. ${ }^{40}$

\section{KESIMPULAN}

Setelah mengumpulkan, mengolah, dan menganalisis data yang diperoleh dari penelitian tentang "Analisis Konsep Pendidikan Islam Humanisme Religius Abdurrahman Mas'ud", maka dapat ditarik kesimpulan bahwa pendidikan Islam Humanisme religius merupakan proses pembentukan karakter, akhlak dan wawasan serta ilmu pengetahuan dengan cara menempatkan manusia sebagai manusia dengan landasan agama yang disertai hubungan manusia dengan Allah SWT dan sesama manusia atau hablun min Allah dan hablun min al-nas. Implementasi dalam pendidikan Islam fokus kepada aspek common sense (akal sehat), individualisme menuju kemandirian, thirst of knowledge (semangat mencari ilmu), pendidikan pluralisme, kontekstualisme lebih mementingkan fungsi dari simbol, dan keseimbangan antara reward and punishment. Secara konseptual, humanisme religius dalam kerangka implikasinya terhadap komponen-komponen pendidikan Islam menawarkan lima

39 Abdurrahaman Mase ud, Menuju Paradigma Islam Humanis, (Yogyakarta: Gama Media, 2003), hlm. 225-226.

40 Abdurrahman Mas'ud, Antologi Studi Agama dan Pendidikan...,hlm. 111. 
komponen inti, yaitu: aspek guru, aspek peserta didik, aspek materi, aspek evaluasi, dan aspek tujuan. Guru dalam menjalankan fungsinya harus dengan kasih sayang, selain itu guru juga merupakan teladan yang baik bagi kehidupan sosial akademis peserta didik. Sementara peserta didik dalam proses mencari ilmu memiliki prasyarat yaitu modal, semangat, waktu memadai, petunjuk guru, kesabaran, dan kecerdasan. Materi iBarat ruh pendidikan untuk membentuk selfidentity peserta didik. Pada aspek metode lebih menekankan pada tuntutan cara berfikir paradigmatik yang menuntut suatu metode tidak hanya diartikan sebagai cara mengajar dalam teaching learning process saja bagi seorang guru tetapi dibanding sebagai upaya perbaikan secara komprehensif dari seluruh elemen pendidikan. Selanjutnya aspek evaluasi, dalam konteks humanisme religius, evaluasi tidak hanya guru yang mengevaluasi siswa namun siswa juga diberi kepercayaan dan tanggung jawab untuk mengevaluasi guru. Aspek terakhir yaitu tujuan, tujuan pendidikan dalam konteks humanisme religius adalah menjadikan hamba Allah yang bertakwa sekaligus sebagai khalifah Allah yang dapat menyelesaikan persoalan-persoalan sosial.

Dalam konteks pendidikan Islam masa kini, pendidikan Islam harus berorientasi pada humanisme religius. Dengan tidak memisahkan dua dimensi ilmu yaitu ilmu agama dan ilmu umum serta dimensi wahyu dan akal yang tetap berjalan seiring dan terpadu dengan berlandaskan pada humanisme dalam proses kegiatan pendidikan Islam. Untuk mewujudkan pendidikan Islam humanisme religius maka lembaga pendidikan Islam bukan hanya mengajarkan ilmu agama saja tetapi juga harus mengajarkan ilmuilmu umum dengan tanpa memisahkanya. Tetapi materi agama dan umum tersebut saling berkaitan dan mendukung demi mengembangkan sikap siswa yang humanis dan mampu menjawab tantangan global. Dalam hal ini, lembaga pendidikan Islam seperti 
madrasah dan Universitas Islam merupakan salah satu bentuk implementasi dari pendidikan Islam humanisme religius, terlepas dari kekurangan yang ada. Namun diharapkan dengan adanya lembaga ini setidaknya sudah dapat menggambarkan pendidikan Islam yang pada dasarnya memiliki landasan humanisme religius.

\section{DAFTAR PUSTAKA}

Abdurakhman, Hasanudin. "Menghafal Itu Bukan Belajar." Kompas.com. Accessed August 20, 2020. https:/ / edukasi.kompas.com/read/2016/12/14/15245261/m enghafal.itu.bukan.belajar?page=all.

Achmadi. Islam Paradigma Ilmu Pendidikan. Yogyakarta: Aditya Media, 1992.

Aminullah, Aam. "Sederet Kasus Tawuran Antar-Pelajar Di Tengah Pandemi Corona." Kompas.com, 2020. https:/ / regional.kompas.com/read/2020/03/28/12252161/s ederet-kasus-tawuran-antar-pelajar-di-tengah-pandemicorona?page=all.

Antaranews.com. "Dua Remaja Tewas Akibat Tawuran Di Matraman." Antaranews.com, 2020. https:/ / www.antaranews.com/berita/1675558/dua-remajatewas-akibat-tawuran-di-matraman.

Arifin, Zainul. "Nilai Pendidikan Humanis-Religius." An-Nuha 1, no. 2 (2014): 53-80.

Assidiq, Yusuf, and Agung Sasongko. “7 Faktor Pemicu Kemajuan Sains Dan Teknologi Peradaban Islam." Republika.co.id, 2017. https:/ / republika.co.id/berita/dunia-Islam/Islamdigest/17/01/24/ok99r1313-7-faktor-pemicu-kemajuan-sainsdan-teknologi-peradaban-Islam.

Budaiwi, Ahmad Ali. Imbalan Dan Hukuman Pengaruhnya Bagi Pendidikan Anak. Jakarta: Gema Insani Press, 2002.

Gustina. "Motivasi Belajar Anak-Anak Nelayan Di Madrasah 
Imam Mukhyidin, Junanah, Mohamad Joko Susilo

Aliyah." Ta'dib 16, no. 2 (2016): 160-67. https:// doi.org/10.31958/jt.v16i2.248.

Hasan, Nur. "Kejayaan Dan Kemunduran Sains Dalam Islam." Alif.id, 2019. https://alif.id/read/nur-hasan/kejayaan-dankemunduran-sains-dalam-dunia-Islam-b221985p/.

Huda, Khoirul. "Problematika Madrasah Dalam Meningkatkan Mutu Pendidikan Islam." Jurnal Dinamika Penelitian 16, no. 2 (December 2, 2016): 309-36. http://ejournal.iaintulungagung.ac.id/index.php/dinamika/article/view/215.

Kelaspintar.id. "Pengaruh Kemajuan Iptek Terhadap Indonesia."

Kelaspintar.id,

2020.

https:/ / www.kelaspintar.id/blog/inspirasi/pengaruh-

kemajuan-iptek-terhadap-Indonesia-4425/.

Langa, Claudiu. "Rewards and Punishments Role in Teacher-Student Relationship from the Mentor's Perspective." Acta Didactica Napocensia 7, no. 4 (2014): 7-12.

Li, Raymond, and Tina Wong. "Teaching Them before We Teach: The Effectiveness of Conducting Classroom Experiments before Teaching the Underlying Theory." IAFOR Journal of Education 6, no. 3

https://doi.org/10.22492/ije.6.3.05.

79-92.

Logar, Ana, Cirila Peklaj, and Vesna Ferk Savec. "Effectiveness of Student Learning during Experimental Work in Primary School." Acta Chimica Slovenica 64, no. 3 (2017): 661-71. https:// doi.org/10.17344/acsi.2017.3544.

Ma'rufi, Amar, Yusuf Suryana, and Heri Yusuf Muslihin. "Hubungan Sikap Berani Dengan Kepercayaan Diri Pada Kegiatan Senam Irama." PEDADIDAKTIKA: Jurnal Ilmiah Pendidikan Guru Sekolah Dasar 5, no. 3 (2018): 287-96.

Mas'ud, Abdurrahaman. Menuju Paradigma Islam Humanis. Yogyakarta: Gama Media, 2003.

Mas'ud, Abdurrahman. Antologi Studi Agama Dan Pendidikan. 
Analisis Konsep Pendidikan Islam Humanisme Religius...

Semarang: Aneka Ilmu, 2013.

Mas'ud, Abdurrahman. Mendakwahkan Smiling Islam: Dialog Kemanusiaan Islam Dan Barat. Tangerang: Pustaka Compass, 2019.

- - - Menggagas Format Pendidikan Non Dikotomik. Yogyakarta: Gama Media, 2002.

Maskur, Muhammad. "Eksistensi Dan Esensi Pendidikan Madrasah Di Indonesia." Jurnal Pendidikan Dan Pembelajaran Dasar 4, no. 1 (2017). https://doi.org/10.24042/terampil.v4i1.1807.

Mighfar, Shokhibul. "Menggagas Pendidikan Humanis Religius: Belajar Dari Model Pendidikan Pesantren." JPII (Jurnal Pendidikan Islam Indonesia) 2, no. 2 (2018): 159-80. https:// doi.org/10.35316/jpii.v2i2.69.

Moleong, Lexy J. Metode Penelitian Kualitatif. Bandung: Remaja Rosdakarya, 1991.

Nafis, Muhammad Muntahibun. Ilmu Pendidikan Islam. Yogyakarta: Teras, 2011.

Nasution, Toni. "Membangun Kemandirian Siswa Melalui Pendidikan Karakter." IJTIMAIYAH 2, no. 1 (2018): 1-18.

Nawawi, Hadari. Metode Penelitian Bidang Sosial. Jakarta: Universitas Gajah Mada Press, 1985.

Nurjanah, Ida. "Paradigma Humanisme Religius Pendidikan Islam: Telaah Atas Pemikiran Abdurrahman Mas'ud." MISYKAT: Jurnal Ilmu-Ilmu Al-Quran, Hadist, Syari'ah Dan Tarbiyah 3, no. 1 (2018): 155-70. https:// doi.org/10.33511/misykat.v3n1.155.

Prasetyo, Sony. "Sains, Teknologi Dan Masa Depan Pembangunan Peradaban." militanIndonesia.org, 2013. https://www.militanIndonesia.org/teori-4/iptek/8468-sainsteknologi-dan-masa-depan-pembangunan-peradaban.html.

Prihantoro, Hijrian A. "Islam Nusantara Dan Filsafat Orientasi Bangsa; Dialektika Modernitas Beragama Dalam Negara 
Imam Mukhyidin, Junanah, Mohamad Joko Susilo

Berbudaya." Millah 16, no. 2 (2017): 203-34. https://doi.org/10.20885/millah.vol16.iss2.art3.

Rahman, Akfa Syaufika, Siti Nurjannah, and Intan Rahma Utami. "Dampak Maraknya Kekerasan Antarpelajar Terhadap Motivasi Belajar." Jurnal Program Kreativitas Mahasiswa 2, no. 2 (2018): 63-69.

Ramadan, Sahri. "Pengaruh Game Online Terhadap Prestasi Belajar Siswa." Kompasiana.com, 2020. https:// www.kompasiana.com/sahriramadan/56e805ebd592 $73 \mathrm{~b} 212 \mathrm{e} 2 \mathrm{bd} 9 \mathrm{e} /$ pengaruh-game-online-terhadap-prestasibelajar-siswa?page=all.

Rogers, Carl. On Becoming a Person (Terj.). Yogyakarta: Pustaka Pelajar, 2012.

Sarjiyati. "Membangun Percaya Diri Dalam Diri Siswa." Radarkudus.jawapos.com, 2019. https:/ / radarkudus.jawapos.com/read/2019/03/15/125253/ membangun-percaya-diri-dalam-diri-siswa.

Tim, CNN Indonesia. "Mengapa Islam Seolah 'tertinggal' Dalam Pengembangan Iptek?" CNN Indonesia, 2020. https://www.cnnIndonesia.com/gayahidup/20200424165738-289-497056/mengapa-Islam-seolahtertinggal-dalam-pengembangan-iptek.

Triningtyas, Diana Ariswanti. "Studi Kasus Tentang Rasa Percaya Diri, Faktor Penyebabnya Dan Upaya Memperbaiki Dengan Menggunakan Konseling Individual." Counsellia: Jurnal Bimbingan Dan Konseling 3, no. 1 (2013): 1-12. https:// doi.org/10.25273/counsellia.v3i1.239.

Uhbiyati, Nur. Ilmu Pendidikan Islam (IPI). 2nd ed. Bandung: Pustaka Setia, 1997.

Undang-Undang Republik Indonesia Nomor 20. Undang-Undang Republik Indonesia Nomor 20 (2003).

Yusep, Wisnu. “Tawuran Pelajar Di Bekasi, Satu Pelajar Tewas 
Ditabrak Motor Lalu Dibacok Berkali-Kali." Okezone, 2020. https:// megapolitan.okezone.com/read/2020/07/23/338/22 51089/tawuran-pelajar-di-bekasi-satu-pelajar-tewas-ditabrakmotor-lalu-dibacok-berkali-kali.

Zydziunaite, Vilma, Margarita Tereseviciene, and Genutè Gedvilienè. "The Structure of Independent Learning in Higher Education: Students' Attitude." In Proceeding of the International Scientifical Conference, 1:336-334, 2014. https:// doi.org/10.17770/sie2014vol1.774. 
Imam Mukhyidin, Junanah, Mohamad Joko Susilo

62 | Millah Vol. 20, No. 1 Agustus 2020 